\title{
2D-3Dハイブリッド津波解析手法の精度 及び大規模化に関する検討
}

\author{
凌国明 ${ }^{1} \cdot$ 松本純一 $^{2} \cdot$ 樫山和男 ${ }^{3}$ \\ 1学生会員 修（工） 中央大学大学院 理工学研究科都市環境学専攻（₹ 112-8551 東京都文京区春日 1-13-27） \\ E-mail: lingguoming@ civil.chuo-u.ac.jp \\ 2 正会員 博 (工) 産業技術総合研究所 機能材料コンピュテーショナルデザイン研究センター \\ （干 305-8568 茨城県つくば市梅園 1-1-1 中央第 2）Ｅ-mail: matsumoto-junichi@aist.go.jp \\ 3 正会員 工博 中央大学教授 理工学部都市環境学科（广 112-8551 東京都文京区春日 1-13-27）
}

E-mail: kaz@civil.chuo-u.ac.jp

\begin{abstract}
本論文は, 著者らが提案した任意領域に基づくオーバーラッピング手法を用いた 2 次元・3 次元ハイブリッド 津波解析手法の精度および大規模化について検討を行ったものである. 精度に関する検討としては, 界面の捕 捉手法に Phase-Field Model の導入を行い，大規模化への対応としては領域分割を用いた MPI に基づく並列計算 手法の導入を行った，本手法の妥当性と有効性を検討するために, 実験結果との比較検討を行うとともに, 実 スケールの大規模計算を実施した。
\end{abstract}

Key Words: 2D-3D parallel computing, free surface flow, phase-field model, Allen-Cahn equation, mass conservation

\section{1. はじめに}

東日本大震災を契機として, 津波に対する被害予測 には従来の浸水域の予測のみでなく構造物の被害予測 も含めたものが求められるようになってきている．著 者らは，既報1 において，広領域の津波解析を合理的に 行う手法として，波源域を含む沖合から海岸近くに対 しては 2 次元浅水長波方程式を用い，対象とする構造 物を含む沿岸地域に対しては 3 次元 Navier-Stokes 方程 式を用いるハイブリッド津波解析手法を提案した。こ の手法は, 任意格子に基づくため, 複雑な地形や構造 物形状への適合性に優れるとともに，3 次元解析領域の 設定が 2 次元解析領域とは独立に行えるため適用性が 高い特徴がある. しかし，3 次元解析領域に対する界面 捕捉手法としては, VOF 法 ${ }^{2}$ が用いられており, 気液 の界面位置を高精度に捕捉するには土夫が必要であっ た。 また，並列計算手法の実装は 3 次元解析領域のみ で，2D-3D ハイブリッド手法における並列化がなされ ていなかったため, 計算効率および大規模化への対応 に課題があった.

そこで，本論文では，3 次元領域の自由表面流れ解 析をより高精度にかつ高速に計算を行うことを目的と して新たに, Allen-Cahn方程式3),4)を用いた Phase-Field Model (PFM) の導入を行うとともに, MPI に基づく 2D3D ハイブリッド並列計算手法を提案する。なお，離散 化手法としては, 非構造格子に基づく安定化有限要素
法5),6),7)を用いた。

次章以降では，2D-3D ハイブリッド解析手法の概要, 界面捕捉手法の検討，MPI に基づく並列化手法につい て述べる. 本手法の有効性を検討するため, 角柱に作 用する流体力問題，孤立波遡上問題を取り上げ，既報に

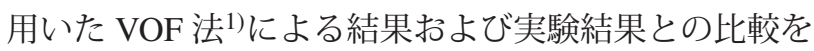
行う。また，大規模計算への適用事例として，2011 年 の東北地方太平洋沖地震により発生した津波のシミュ レーションを行う。

\section{2D-3D ハイブリッド解析手法}

本節では，本手法で用いる 2D-3D ハイブリッド解析 手法の概要, 支配方程式, 離散化手法について述べる.

\section{（1） 2D-3D ハイブリッド解析手法の概要}

本研究は，図一 1 に示す任意格子に基づくオーバー ラッピング手法 ${ }^{1)}$ を用いる. 図のように解析対象に対し て, 2 次元解析領域と 3 次元解析領域の一部がお互い に重なっているオーバーラップ領域を設置する．なお， 津波の影響が 3 次元解析領域に及ぶまでは, 全体を浅 水長波方程式に基づく 2 次元解析のみで行うため, 2 次 元メッシュは陸域を含む解析領域全体に対して用意す る. そのため, 3 次元解析領域の設定とメッシュ分割は 2 次元解析領域のそれらとは独立に自由に設定可能であ り, 適用性が高い特徵をもっている. 2 次元解析領域と 
3 次元解析領域の接続は, 図- 2 に示す接続境界上で, 水位の適合条件と連続条件（流量の保存）の考慮によ り行う。流量の保存については, 図一 2 に示すように 2 次元解析により計算された流速と水深を 3 次元解析領 域の 3D 接続境界条件とし, 同様に，3 次元解析により 得られた流速と VOF 関数を 2 次元解析領域の $2 \mathrm{D}$ 接続 境界条件として相互に与えている。 なお, 既往研究に おいてオーバーラップ領域に含まれる要素数について は 4 要素程度とることで滑らかな接続が可能となる知 見が得られている11.

図ー3に本ハイブリッド手法のフローチャートを示す．

\section{(2) 支配方程式}

波源域を含む沖合から海岸近くまでの津波伝播解析 に用いる支配方程式としては，浅水長波近似を用いた 2 次元浅水長波方程式を採用する. 浅水長波方程式 (1) と連続式 (2) を以下に示す.

$$
\begin{aligned}
& \frac{\partial\left(U_{i} H\right)}{\partial t}+\frac{\partial\left(U_{j} U_{i} H\right)}{\partial x_{j}}+\nu_{e} \frac{\partial^{2}\left(U_{i} H\right)}{\partial x_{j}^{2}} \\
& +\frac{g n^{2} U_{i} \sqrt{U_{j} U_{j}}}{H^{\frac{1}{3}}}+g H \frac{\partial(H+z)}{\partial x_{i}}=0 \\
& \frac{\partial H}{\partial t}+\frac{\partial\left(U_{i} H\right)}{\partial x_{i}}=0
\end{aligned}
$$

ここに, $U_{i}$ は $x_{i}$ 方向の断面平均流速, $H$ は全水深, $g$ は重力加速度, $\nu_{e}$ は渦動粘性係数, $n$ はマニングの粗 度係数, $z$ は地盤高である.

一方, 3 次元領域に対しては, Navier-Stokes 方程式 (3) と連続式 (4)を用いる.

$$
\begin{aligned}
& \rho\left(\frac{\partial u_{i}}{\partial t}+u_{j} \frac{\partial u_{i}}{\partial x_{j}}-f_{i}\right)+\frac{\partial p}{\partial x_{i}} \\
& -\mu \frac{\partial}{\partial x_{j}}\left(\frac{\partial u_{i}}{\partial x_{j}}+\frac{\partial u_{j}}{\partial x_{i}}\right)=0 \\
& \frac{\partial u_{i}}{\partial x_{i}}=0
\end{aligned}
$$

ここに, $u_{i}$ は流速, $p$ は圧力, $f_{i}$ は物体力, $\rho$ は密度, $\mu$ は粘性係数である.

\section{(3) 離散化手法}

支配方程式(1)，(2) に対しては SUPG 法に基づく安定 化有限要素法5),7)を, 式(3), (4)に対しては SUPG/PSPG 法に基づく安定化有限要素法6),11)を適用する. そして, 2 次元解析領域に対しては三角形 1 次要素, 3 次元解 析領域に対しては四面体 1 次要素を用いて, 空間方向 の離散化を行う。一方, 時間方向の離散化には CrankNicolson 法に基づく差分近似を適用する. また，連立 一次方程式の解法には Element-By-Element 処理による Bi-CGSTAB 法を適用する. 離散化及びアルゴリズムの 詳細は, 文献1を参照されたい。
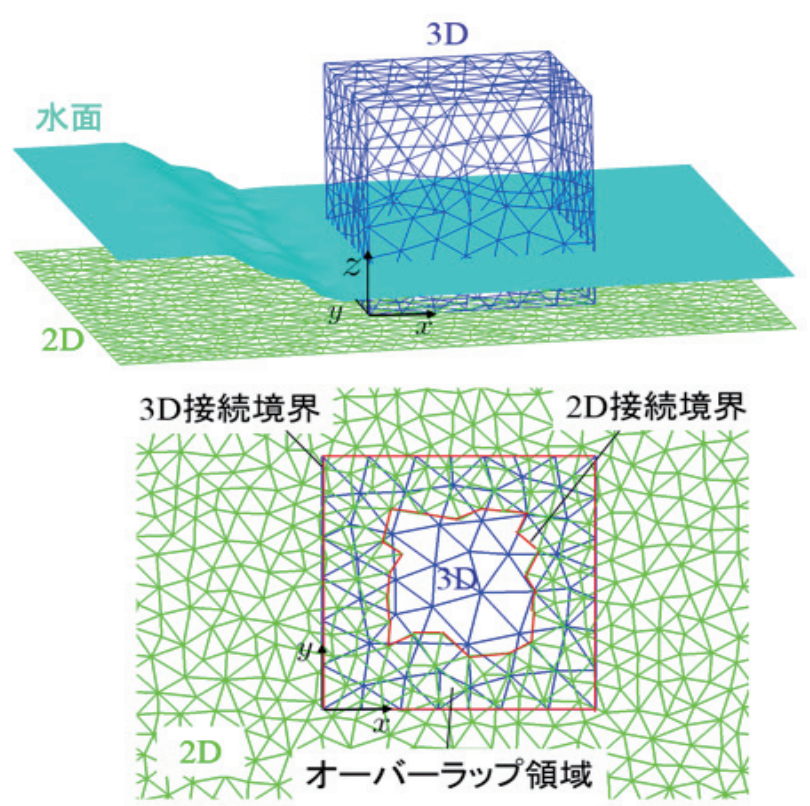

図-1 オーバーラッピング手法

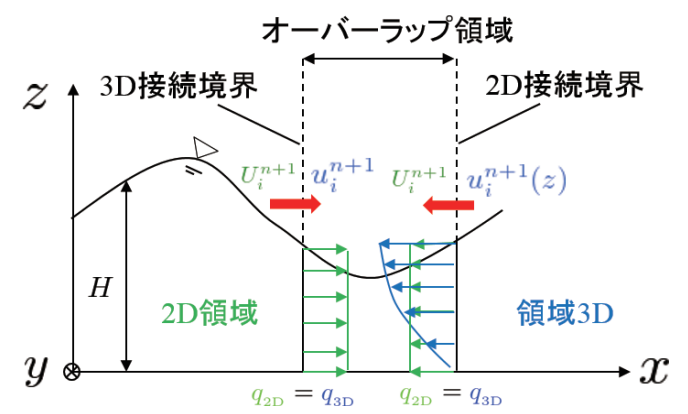

図-2 接続境界における流量保存性条件

\section{3. 界面捕捉手法}

3次元解析領域における界面の捕捉手法として, 本論 文では既報に用いた VOF 法1) と今回新たに用いる PFM の比較を行う。

\section{(1) 支配方程式}

支配方程式としては，VOF 法は移流方程式 (5), PFM は Allen-Cahn 方程式 (6) ${ }^{3), 4)}$ を用いている.

$$
\begin{gathered}
\frac{\partial \phi}{\partial t}+u_{j} \frac{\partial \phi}{\partial x_{j}}=0 \\
\frac{\partial \phi}{\partial t}+u_{j} \frac{\partial \phi}{\partial x_{j}}=-M_{a}\left[\xi(\phi)-k_{\phi}\left(\frac{\partial^{2} \phi}{\partial x_{j}^{2}}+\kappa\left|\frac{\partial \phi}{\partial x_{k}}\right|\right)\right]
\end{gathered}
$$

ここで, $\phi$ は界面関数であり, 液体であれば 1.0 , 気体 であれば 0.0 , 気液界面は 0.5 と定義する. また, AllenCahn 方程式において, $M_{a}, \xi(\phi), k_{\phi}, \kappa$ は次式のよう 
に表される.

$$
\begin{gathered}
M_{a}=\frac{2 b^{2}}{\delta^{2}} M \gamma, b=2 \tanh ^{-1}(1-2 \lambda), \delta=a_{\delta} h_{\delta}, \\
\xi(\phi)=\frac{\partial f(\phi)}{\partial \phi}, f(\phi)=\phi^{2}(1-\phi)^{2}, \\
k_{\phi}=\frac{\delta^{2}}{2 b^{2}}, \\
\kappa=\nabla \cdot \mathbf{n}, \mathbf{n}=\frac{\nabla \phi}{|\nabla \phi|} .
\end{gathered}
$$

ここに, $M, \gamma, \delta, h_{\delta}, \kappa, \mathbf{n}$ はそれぞれ界面モビリ ティー, 界面エネルギー, 連続的に変化する気液界面 幅, 要素の代表長さ, 界面曲率, 界面法線ベクトルで ある. なお， $a_{\delta}$ は気液界面幅を決める係数で, 本論文 では $a_{\delta}=3.0$ としている. また, $\lambda=0.1$ としている.

各要素に打ける密度 $\rho$ と粘性係数 $\mu$ に関しては, 次 式10)で決定される.

$$
\begin{gathered}
\rho=\frac{\rho_{l}+\rho_{g}}{2}+\frac{\rho_{l}-\rho_{g}}{2} \sin \left[\frac{\phi-\left(\phi_{l}+\phi_{g}\right) / 2}{\phi_{l}-\phi_{g}} \pi\right] \\
\mu=\frac{\mu_{l}+\mu_{g}}{2}+\frac{\mu_{l}-\mu_{g}}{2} \sin \left[\frac{\phi-\left(\phi_{l}+\phi_{g}\right) / 2}{\phi_{l}-\phi_{g}} \pi\right]
\end{gathered}
$$

ここに, $\rho_{l}, \rho_{g}, \mu_{l}, \mu_{g}$ はそれぞれ液体, 気体の密度及び 粘性係数である.なお, PFM 法ではダブルウェルポテ ンシャルの項を用いているため, 界面幅を一定に保つ 効果に加え, 界面関数のオーバーシュートおよびアン ダーシュートが発生しない特徴がある，このため, 高 精度でかつ保存性の高い計算が期待できる。

\section{(2) 離散化手法}

Allen-Cahn 方程式の離散化に対して, SUPG 法に基 づく安定化有限要素法を適用すると, 以下に示すよう な重多付き残差式が得られる.

$$
\begin{aligned}
& \int_{\Omega} \psi^{*}\left(\frac{\partial \phi}{\partial t}+u_{j} \frac{\partial \phi}{\partial x_{j}}+M_{a} \xi(\phi)-M_{a} k_{\phi} \kappa\left|\frac{\partial \phi}{\partial x_{k}}\right|\right) d \Omega \\
& -\int_{\Omega} \psi^{*} M_{a} k_{\phi} \frac{\partial^{2} \phi}{\partial x_{j}^{2}} d \Omega+\sum_{e=1}^{n_{e l}} \int_{\Omega} \tau_{\mathrm{SUPG}} u_{j} \frac{\partial \psi^{*}}{\partial x_{j}}\left(\frac{\partial \phi}{\partial t}\right. \\
& \left.+u_{j} \frac{\partial \phi}{\partial x_{j}}+M_{a} \xi(\phi)-M_{a} k_{\phi} \kappa\left|\frac{\partial \phi}{\partial x_{k}}\right|\right) d \Omega=0
\end{aligned}
$$

ここで， $\psi^{*}$ は式 (6) に対する Galerkin 項の重み関数で ある. 第 3 項は安定化項であり， $\tau_{\mathrm{SUPG}}$ は次式で定義 される安定化パラメータである.

$$
\tau_{\mathrm{SUPG}}=\left[\left(\frac{2}{\Delta t}\right)^{2}+\left(\frac{2\left\|\mathbf{u}^{h}\right\|}{h_{e}}\right)^{2}\right]^{-\frac{1}{2}}
$$

\section{ここで, $\Delta t$ は時間増分量, $h$ は要素長である.}

空間方向の離散化には四面体 1 次要素を用い, 時間 方向の離散化には 2 次精度を有する Crank-Nicolson 法 を適用する。ここで, 式 (13)の $\xi(\phi)$ 及び界面曲率に関 する項の $\phi$ は式 (15), (16) に示す Adams-Bashforth 法

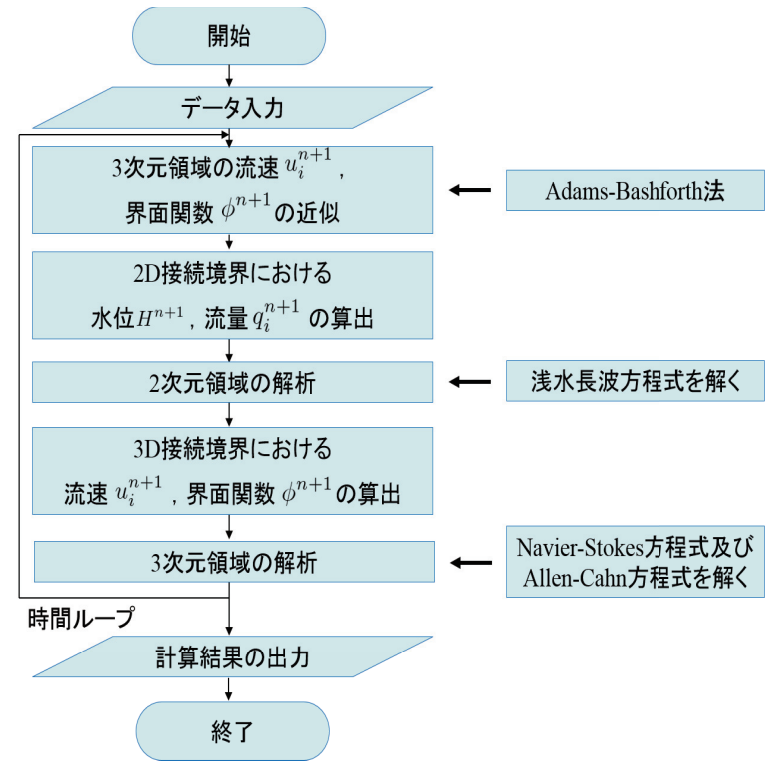

図-3 解析のフローチャート

により陽的に近似し，線形化した Phase-Field 関数を代 入している.

$$
\begin{gathered}
\phi^{*}=\frac{3}{2} \phi^{n}-\frac{1}{2} \phi^{n-1} \\
\widetilde{\phi}^{n+1} \approx 2 \phi^{*}-\phi^{n}
\end{gathered}
$$

連立一次方程式の解法には, Element-By-Element 処 理による Bi-CGSTAB 法を適用する.

\section{2D-3D ハイブリッド津波解析手法におけ る並列化}

\section{(1) 並列計算手法}

2D-3D ハイブリッド計算における計算の高速化, 及び 大規模化を行うための手法として, MPI (Message Passing Interface) に基づく並列計算手法の導入を行う．並列 計算手法としては, 領域分割法に基づく手法 ${ }^{12)}$ を用い, 領域分割手法としては METIS を用いる.これにより各 ノードに割り当てる要素数はほぼ均等化されたものと なる。

\section{（2） 2D-3D オーバーラッピング手法の並列化}

本項では, 2 次元・3 次元のオーバーラッピング手法 11 （解析のフローチャートは図ー3 参照）に対する並列化 について述べる. 図-4k, 2 次元領域と 3 次元領域の オーバーラップ領域付近におけるメッシュ図（(A) は 底面のメッシュ図, (B) は表面メッシュの鳥瞰図) を示 す. オーバーラップ領域の 3 次元メッシュの境界は 3D 接続境界, 2 次元メッシュの境界は $2 \mathrm{D}$ 接続境界と定義 する. そして, 2 次元解析領域と 3 次元解析領域に対し ては領域分割に基づく並列計算を行うため領域分割を 行う。なお，図-4 中の○数字は領域番号を示してい 


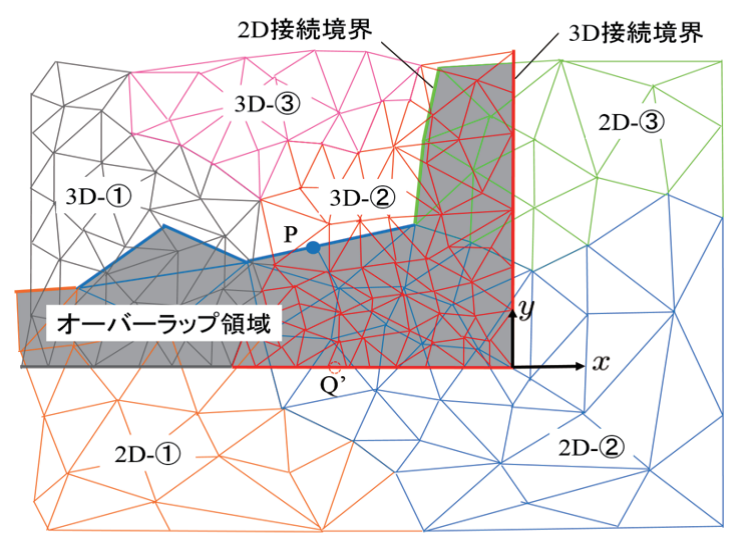

○:2D接続境界上における任意の節点 $\mathrm{P}$

(A) 底面のメッシュ図

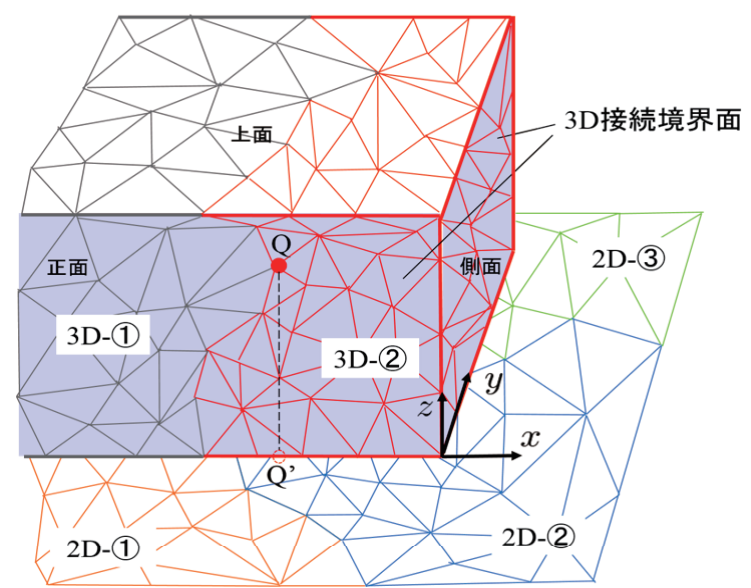

○:3D接続境界上における任意の節点 $\mathrm{Q}$

: 節点 $\mathrm{Q}$ が2次元領域に投影した点 $\mathrm{Q}^{\prime}$

(B) 表面メッシュの鳥瞰図

図-4 オーバーラップ領域の付近における領域分割図

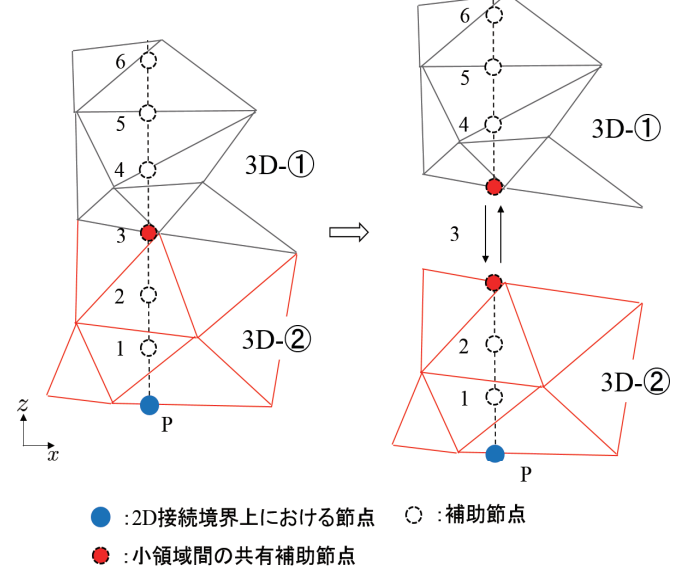

図-5 2D 接続境界の任意節点 P の物理量の算定法

る. 図ー 5 に 2D 接続境界上の 2 次元メッシュの任意 節点 $\mathrm{P}$ (図一 2 における $2 \mathrm{D}$ 接続境界）における物理量 (流速と水深) を求める模式図を示す．まず，プリプロ セスとしてあらかじめ図ー4 (A) に示す 2D 接続境界

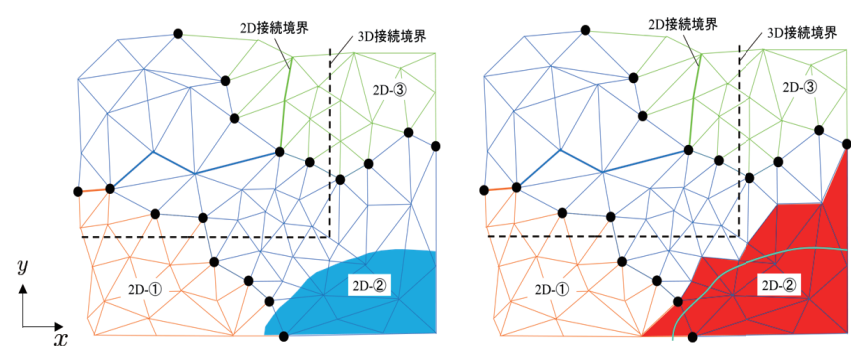

(A) 波が2次元領域のみに存在する場合

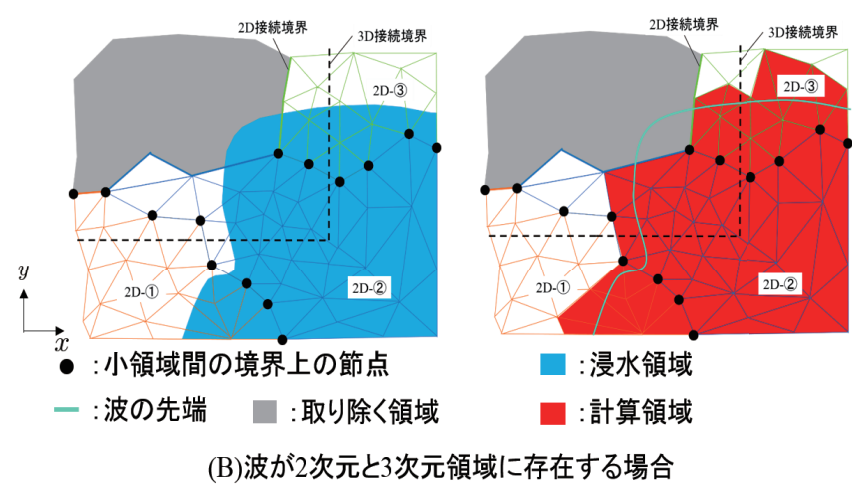

図-6 移動境界処理

上における 2 次元メッシュのすべての節点の鉛直方向 に等間隔で補助節点を配置し, それぞれの補助節点が 領域分割された 3 次元領域のどの小領域及びどの要素 に含まれるかを検索して記憶する（図一 5 において点 $\mathrm{P}$ の補助節点 3 は小領域の境界上に存在している). そし て, 各時間ステップにおいて, 補助節点が含まれる要 素内で 1 次補間することで, 補助節点の界面関数, 流 速を求める. なお, 補助節点の間隔については, 3 次元 領域のメッシュ幅に応じて決めている. 次に, 点 $\mathrm{P} に$ おける平均流速と水深は鉛直方向の補助節点の值を用 いて積分することで算出する. なお，図－5 に示すよ うに鉛直方向の補助節点が複数の領域に存在する場合 には，小領域ごとに求めた值を節点 $\mathrm{P}$ が属する小領域 に通信を行う。また，その際には小領域間の共有節点 （図一-5では節点 3）ではその点が含まれる領域数で割 ることで, 重複の影響を除く. また, 3D 接続境界上に おける 3 次元メッシュの任意節点 $\mathrm{Q}$ の值を求めるため に, 2 次元のメッシュへの投影節点 Q' がどの小領域及 びどの要素に含まれるかを探索する. そして, 含まれる 要素の節点值を用いて 1 次補間により Q'の值を求め, $\mathrm{Q}$ ’の值を用いて $\mathrm{Q}$ 点の值を算出する.

\section{(3) 2D-3D ハイブリッドモデルにおける 2 次元領域の} 移動境界処理

2 次元領域における浅水長波方程式に基づいた津波解 析においては, 水際線の先端の移動を考慮する必要が ある. 本研究では固定メッシュを用いる Euler 的手法に 
基づく移動境界手法5),7)を適用する. まず，プリプロセ スとしてあらかじめ図ー6 9 3D 接続境界上に等間隔 で 2 次元の補助節点を配置し, 補助節点の毎ステップ の水位を求めるために, その補助節点を含む要素を記 憶する. また，図中の黒点は領域分割された各小領域 の境界上の点であり, それらの点については何番目の 小領域上にあるかを記憶する。各時間ステップにおい て以下の手順により移動境界処理を行う.

（1）各小領域の全節点に対し, 微小水深を用いて水域 要素, 水際要素, 陸域要素の判別を行う. 図一6(A) は波が 2 次元領域のみに存在する場合であり, こ の場合には，ハイブリッド計算は行わず 2 次元計 算のみが実施される. 左の図は水色の領域が水域 を表しており, 右図では波の先端は水色で示して いる. Euler 的手法では水際線を含む要素は水際要 素であり赤色で示す計算領域に含める.

（2）3D 接続境界上の補助節点の水位をその補助節点を 含む要素の節点値を用いて 1 次補間により求める. そして, 初期水位より高くなった場合には, 図一 6(B) に示すように 3 次元領域にも波が存在するこ とになり, その際には 3D 接続境界内のオーバー ラップ領域以外の 2 次元要素 (図- 6(B) の灰色領 域の要素）は計算領域から除外する。

(3) 隣接プロセッサ間通信と全プロセッサ間通信を用 いて, 連立一次方程式を求解する. その際には, 連 立一次方程式の内積計算（全プロセッサー間通信） において図中の黒点での重複に注意する.

\section{5. 数值解析例}

\section{（1）角柱に作用する抗力問題}

PFM 法による 3 次元自由表面流れ解析手法の妥当性 を検証するため, 図一 7 に示すような矩形水槽内の角柱 に作用する抗力問題 ${ }^{13)}$ を取り上げ, VOF 法と PFM 法の 比較を行った. 初期条件としては, 水理実験と同様に, 長方形の水槽の片側に水を貯め, 瞬時に自由流出させる. 水, 空気の密度と粘性係数はそれぞれ, $\rho_{l}=998.0 \mathrm{~kg} / \mathrm{m}^{3}$, $\rho_{g}=1.205 \mathrm{~kg} / \mathrm{m}^{3}, \mu_{l}=1.01 \times 10^{-3} \mathrm{~Pa} \cdot \mathrm{s}, \mu_{g}=1.81 \times 10^{-5} \mathrm{~Pa} \cdot$ $\mathrm{s}$ を与える. また, PFM 法の界面幅は要素の代表長さの 3 倍と仮定した. 解析メッシュとしては, 図一 8 に示す ような粗密づけした非構造格子を用いる. 最小メッシュ 幅は $0.005 \mathrm{~m}$ であり, 総節点数は 998,071 , 総要素数は $5,757,462$ である. また, 時間増分量は $0.001 \mathrm{~s}$ とし, 境 界条件としては slip 条件を適用した。 なお, 本論文で は曲率の影響は無視した。

図ー9に角柱の $x$ 軸方向に働く抗力の時刻歴を示す. 図より, 数值解析結果はいずれも実験結果よりやや早く 角柱に到達しているが, 抗力の最大值は良い一致を示

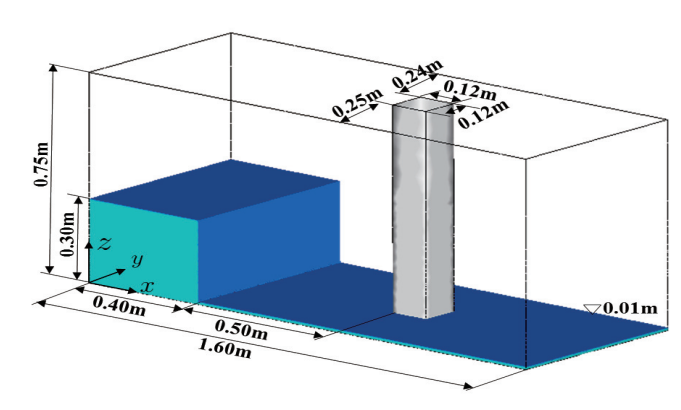

図-7 角柱に作用する抗力問題

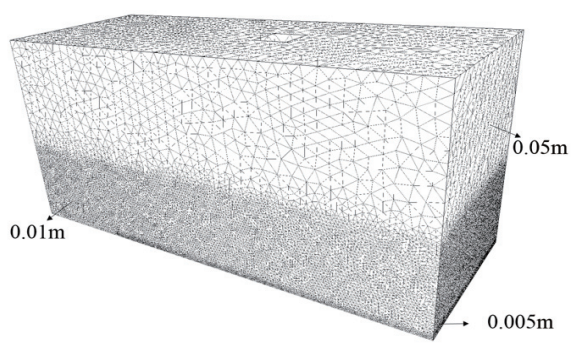

図-8 解析メッシュ

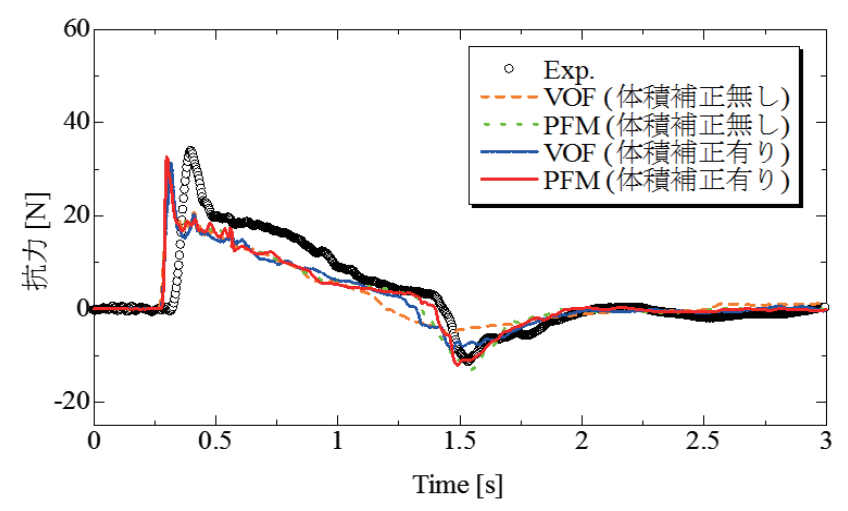

図-9 角柱の $x$ 軸方向に作用する抗力の時刻歴

している. また, PFM 法を用いた解析結果は VOF法に 比べて, 反射波についてより良く抗力の変化をとらえ ていることが分かる。体積補正手法6)を適用した PFM 法の解析結果は最も実験結果と一致しているが, 体積 補正の効果はVOF 法に比べて限定的であることが分か る.これは, PFM 法は界面幅を一定に保つ効果に加え, 界面関数のオーバーシュートおよびアンダーシュート が発生しない特徴があることに起因する. 図一 10 に反 射波が角柱に戻る $t=1.50 \mathrm{~s}$ における両者の結果の比較 を示す. 図より, PFM 法を用いた解析結果の方が水面 が安定に計算されており, かつVOF 法に比べて界面幅 がほぼ一定に保たれていることが分かる。また, 図一 11 に体積保存率の時刻歴の比較を示す. 図より, 同じ 安定化手法で離散化した場合には, PFM 法の方が VOF 


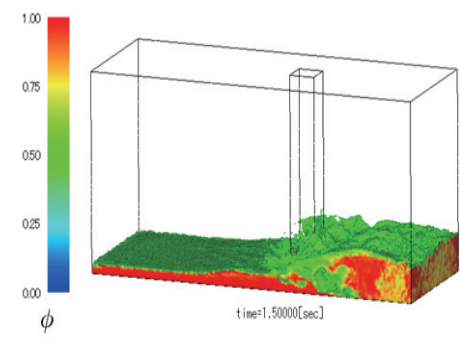

(A) VOF (体積補正無L)

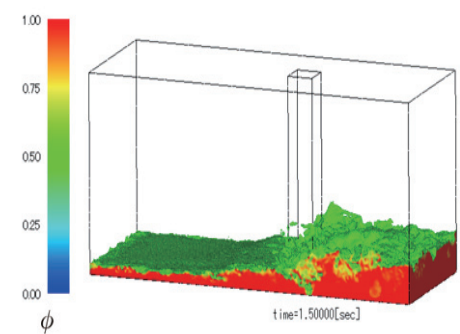

(C) VOF (体積補正有り)

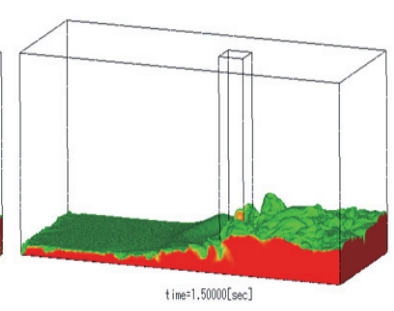

(B) PFM (体積補正無し)

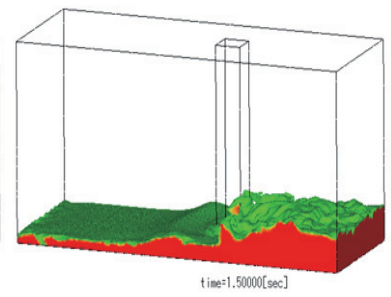

(D) PFM (体積補正有り)
図-10 $t=1.50 \mathrm{~s}$ における自由表面形状の比較

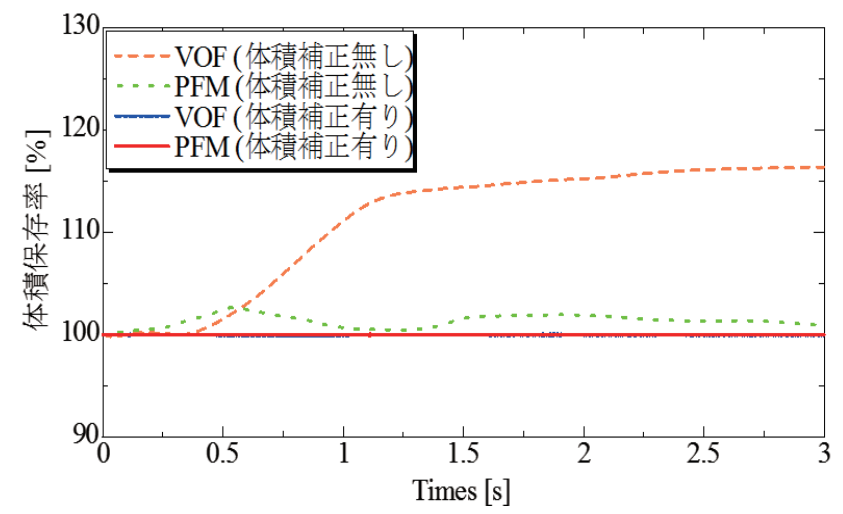

図-11 体積保存率の時刻歴の比較

法に比べて保存性が良いことが分かる。なお，保存性 が満足されない理由は, 移流方程式に非保存系のもの を用いていることが起因する．また，体積補正手法6)を 適用することで両手法ともに体積保存率は $100 \%$ となる ことが確認できた. ただし, 本例題は 3 次元解析領域 内の水の体積は不変であるため, 体積補正手法は適用 可能であるが, 以後のハイブリッド解析を用いた数值 解析例では, 3 次元領域内の水の体積は流入・流出の影 響により変化するため, 体積補正手法は用いていない.

\section{(2) 孤立波遡上問題}

図ー 12 に示すような孤立波遡上問題を取り上げ, VOF 法を用いた場合と PFM 法を用いた場合の 2 次元・3 次 元ハイブリッドモデルの比較を行った.

初期条件として, 波高水深比 $\zeta_{0} / h=0.3$, 初期波高

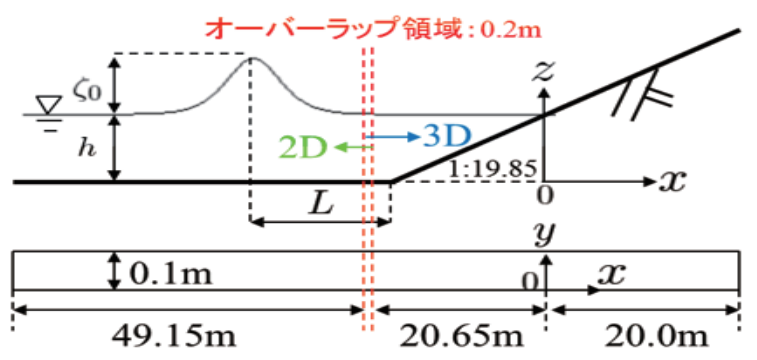

図-12 解析モデル

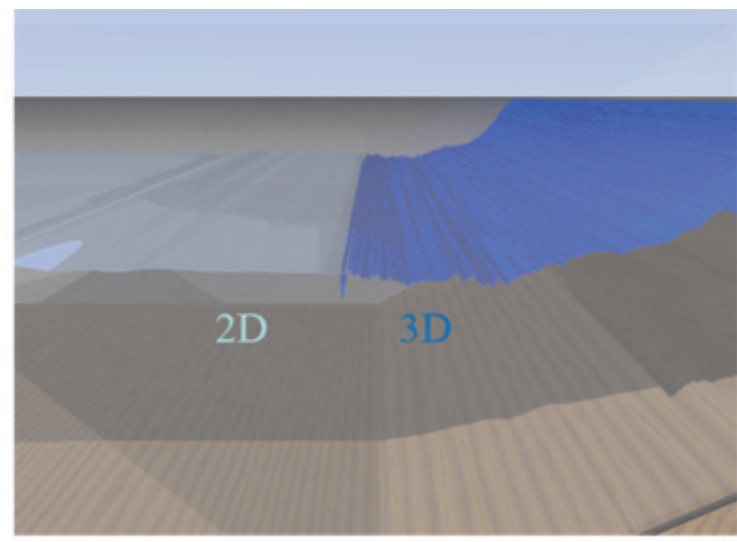

(A) VOF法を用いた2D-3D Hybrid Model

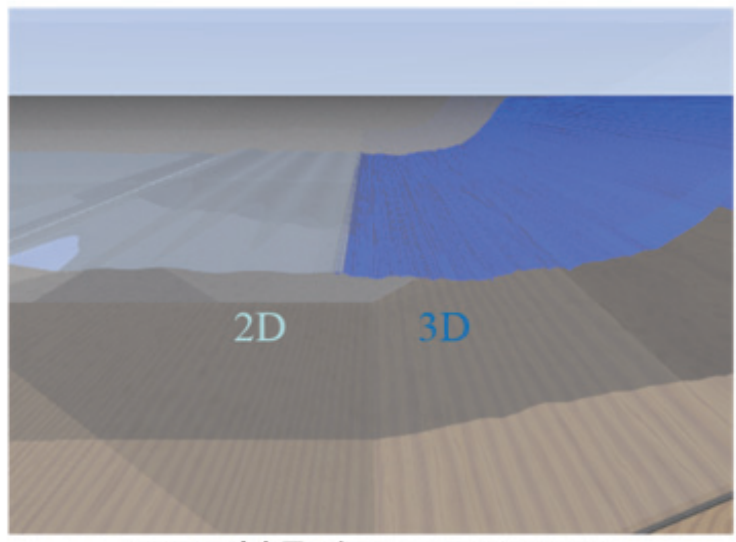

(B) PFM法を用いt=2D-3D Hybrid Model

図-13 $t=4.0 \mathrm{~s}$ における水面形状の比較

は式 (17) で与える.

$$
\zeta(x, t=0)=\frac{\zeta_{0}}{h} \operatorname{sech}^{2} \sqrt{\frac{3 \zeta_{0}}{4 h}}\left(x-x_{0}\right)
$$

ここで， $x_{0}$ は波峰の位置である. 初期流速は式 (18)で 与える。

$$
u(x, t=0)=\zeta(x, t=0) \sqrt{\frac{g}{h}}
$$

また, 波峰は水深変化点から式 (19) で示される孤立波 の半波長 $L$ の位置にある.

$$
L=\sqrt{\frac{4 h}{3 \zeta_{0}}} \operatorname{arccosh}\left(\sqrt{\frac{1}{0.05}}\right)
$$

2 次元解析領域の有限要素分割は, 三角形 1 次要素に よる構造格子 (節点数 2,964 , 要素数 3,948 ) を用い, 最 

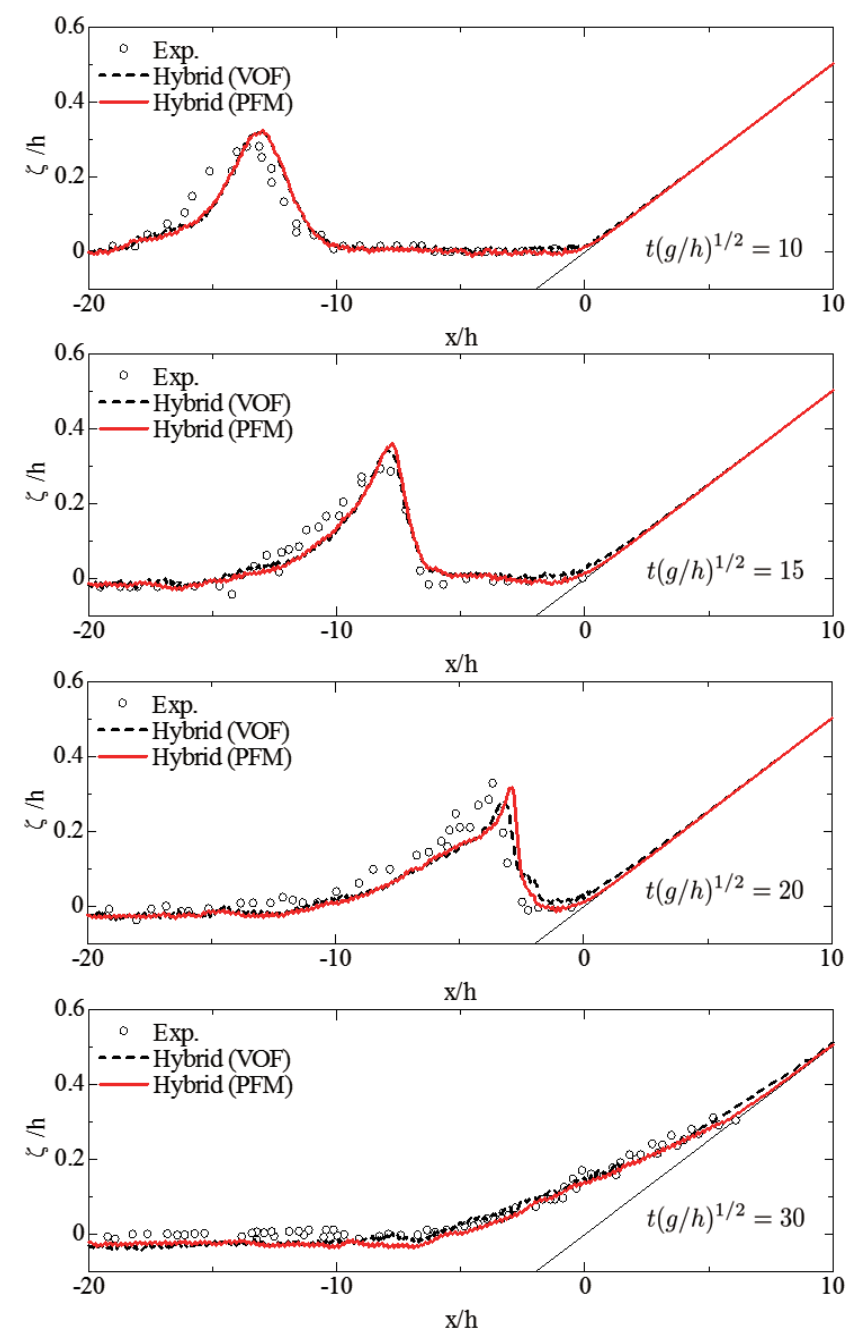

図-14 波形の実験結果と解析結果の比較 $\left(t^{\prime}=10,15,20,30\right)$

小メッシュ幅は $0.05 \mathrm{~m}$ である. 一方, 3 次元解析領域 では, 四面体 1 次要素による構造格子 (節点数 100,614, 要素数 392,160) を用い, 最小メッシュ幅は $0.05 \mathrm{~m}$ であ る.なお，時間増分量は $0.005 \mathrm{~s}$ とした。

境界条件として，接続面を除く壁面境界上に slip 条 件を用い. 渦動粘性係数 $\nu_{e}$ は $1.0 \times 10^{-3} \mathrm{~m}^{2} / \mathrm{s}$, マニ ングの粗度係数 $n$ は $0.01 \mathrm{~s} / \mathrm{m}^{\frac{1}{3}}$ を仮定した.

図一 13 に $t=4 \mathrm{~s}$ における 2次元と 3 次元のオーバーラ ップ領域付近の水面形状を示す, 図より PFM法を用いた 場合の方が水面が滑らかに接続されていることが分かる.

図－14 に無次元化した時刻 $t^{\prime}=t \sqrt{\frac{g}{h}}=10,15,20,30$ における波形の実験結果 ${ }^{14)}$ と解析結果との比較を示す. $t^{\prime}=20$ の図より, PFM 法を用いた場合の方が VOF 法 に比べてピーク值及び波形が実駼結果と良い一致して いることが分かる.

\section{(3) 実地形津波解析}

本手法の大規模解析への適用事例として, 東北地方 太平洋沖地震により発生した津波シミュレーションを

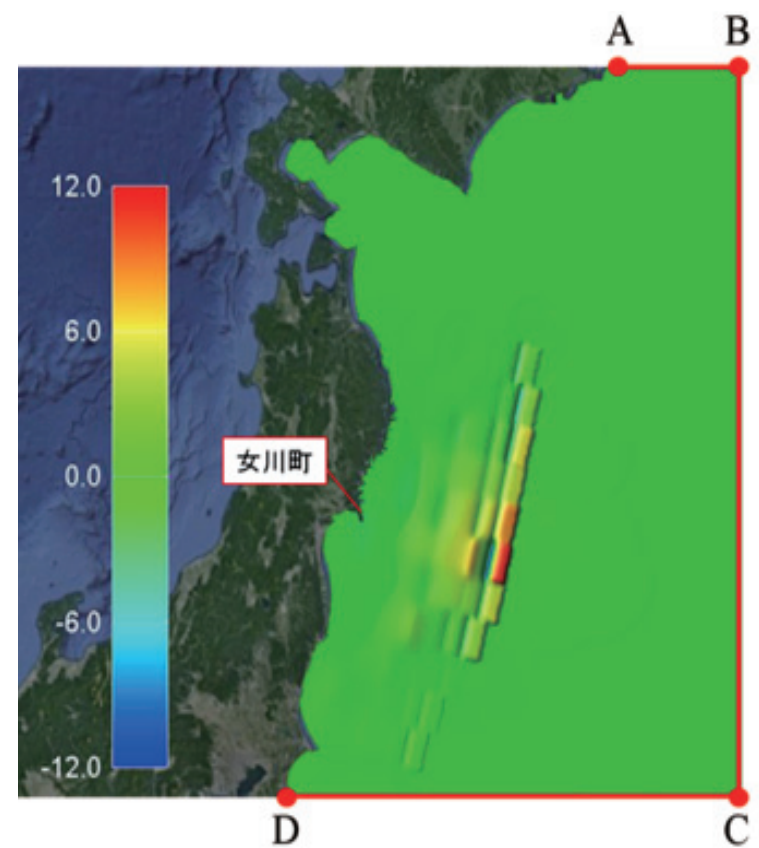

図-15 解析モデル（初期条件）

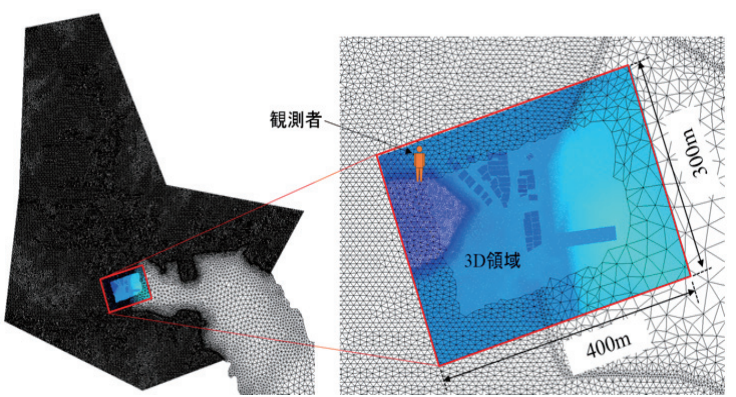

図-16 3 次元解析領域（女川町の海岸付近）及び観測者位置

行った. 図ー 15 に，全体の解析領域と初期条件を示す. 3 次元の計算領域は女川町の海岸付近とする（図-16 参照, 図中可視化するための視点（観測者）を示して いる）. 初期条件として与える水位変動量の計算には Mansinha \& Smylie の方法 ${ }^{15)}$ を用い, 断層モデルには佐 竹らによる Ver. 8.0（55 小断層モデル） 16)を用いた. 境 界条件は海岸部で反射境界条件 (non-slip 条件) を与え, 沖合 $\mathrm{ABCD}$ では開境界条件として与える. また, 2 次 元メッシュの節点数は 557,252 , 要素数は $1,103,938$ で あり, 3 次元メッシュの節点数は $23,232,416$, 要素数は 134,768,640である. 解析領域は METIS により図ー 17 のように 512 の小領域に分割し, 時間増分量を $0.1 \mathrm{~s}$ と 設定して，2,050s 経過時まで計算を行った。なお，並列 計算機としては京都大学のスーパーコンピュータ（Cray XC40）使用した.

図一 18 (A),(B) に 720s 時, 2,000s 時の 2 次元領域の 解析結果を示す．図より，沖合で発生した津波が，時間 経過とともに沿岸部へ伝播していく様子が分かる. ま た，図ー 19 (A),(B),(C) に高台にいる観測者位置（図一 


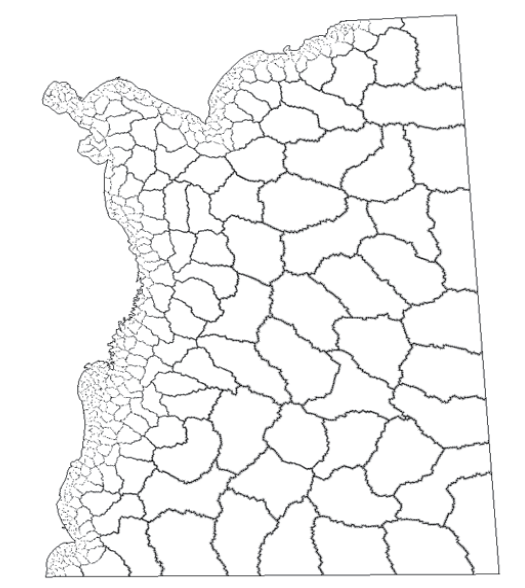

2次元領域

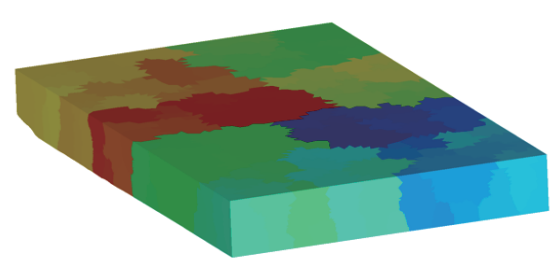

3次元領域

\section{図-17 解析領域の分割図 (512 分割)}

16 参照）からのシミュレーション結果を示す. 図ー 19 中の緑色は 2 次元の解析結果, 水色は 3 次元の解析結 果を表している。図－19より，1,920s 後に津波が 3 次 元解析領域に到達し, ハイブリッド計算が始まり, そ して，建物周辺に浸水してくる様子が確認できる。な お，計算時間に関しては 2 次元で逐次計算，3 次元で 並列計算を行う既報の手法の場合では，波が 3 次元領 域に到達するまでの計算時間は $184,895 \mathrm{~s}$ (1 ステップあ たり 9.67s）であり，波が到達してからのハイブリッド 解析における 2 次元解析と 3 次元解析の計算時間の割 合は約 $35 \%$ と約 $65 \%$ であった。また，1 ステップあた りの計算時間は約 $27 \mathrm{~s}$ と約 49s（最初の 10 ステップの 平均值) であった. 一方, 2 次元と 3 次元両方に対して 提案した並列計算手法を適用した場合では, 波が 3 次 元領域に到達するまでの計算時間は 2,247s（1 ステップ あたり $0.12 \mathrm{~s}$ ，逐次計算に比べて約 1/80）であり，波が 到達してからのハイブリッド解析における 2 次元解析 と 3 次元解析の計算時間の割合は約 $22 \%$ と約 $78 \%$ で あった. また, 1 ステップあたりの計算時間は約 $15 \mathrm{~s}$ と 約 $52 \mathrm{~s}$ (最初の 10 ステップの平均值) であった. なお, Bi-CGSTAB 法の収束判定については, 2 次元及び 3 次 元の単体で解く場合には, 相対残差ノルムで $10^{-12}$ と しているが, 流入流出を伴うハイブリッド計算では任 意メッシュによるオーバーラップを許容している点及 びメッシュサイズの差異により収束がいく分悪くなり, 計算時間の観点から $10^{-6}$ とした。

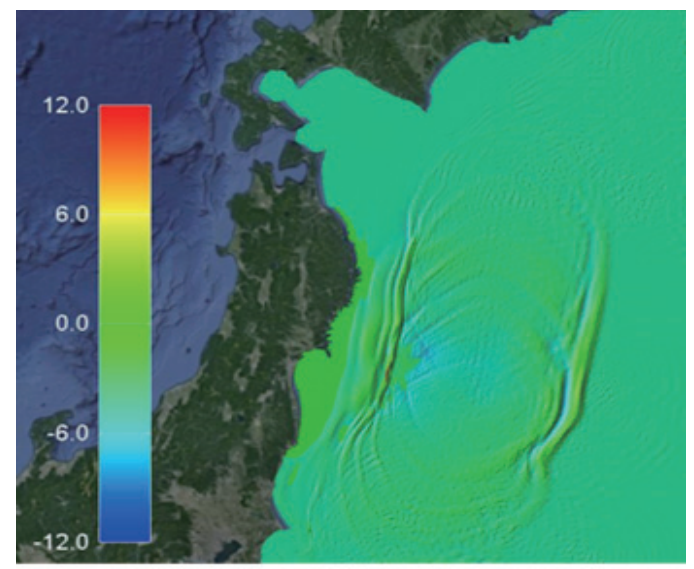

(A) $\mathrm{t}=720 \mathrm{~s}$

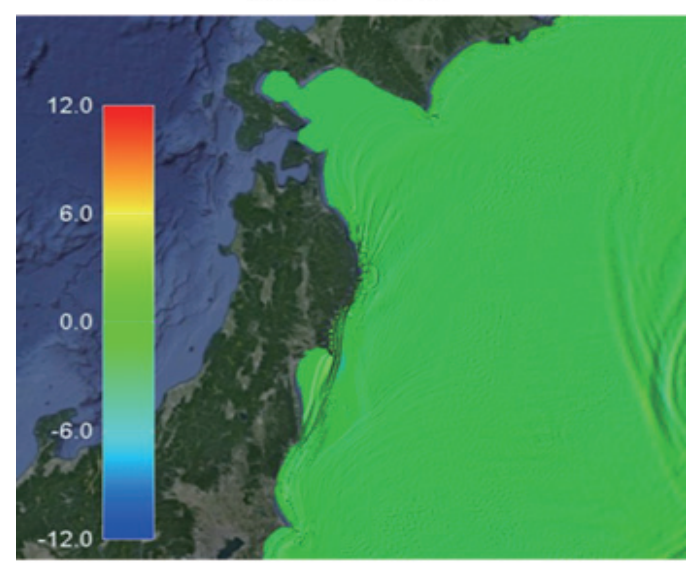

(B) $\mathrm{t}=2,000 \mathrm{~s}$

\section{図-18 解析結果}

\section{6. おわりに}

本論文では，任意格子に基づく 2 次元・ 3 次元ハイブ リッド津波解析手法に対して, 高精度化と大規模化に ついて検討を行った. 精度に関する検討としては, 界面 の捕捉手法に Phase-Field Model (PFM) の導入を行い, 大規模化への対応としては領域分割を用いた MPI に基 づく並列化手法の導入を行った. 数值解析例を通じて 以下の結論を得た。

- 自由表面流れ問題の検証として, 角柱に作用する 抗力問題を取り上げ, 従来の VOF 法による結果と の比較を行った。その結果，PFM 法を用いた結果 はVOF 法に比べて，保存性も高く実験結果と良い 一致を示した.

- 2D-3D ハイブリッド津波解析手法を用いた検証と して，孤立波遡上問題を取り上げた結果，PFM 法 を用いた場合はVOF法を用いた場合に比べて，結 合部における水面形がより安定であり, 実験結果 とも良い一致を示した。

・ MPI に基づく 2D-3D ハイブリッド津波並列計算手 法を東北地方太平洋沖地震津波の大規模計算の事 
例に適用した結果，計算の大規模化が実現でき計 算時間の大幅な短縮が実現できることを示した.

今後は，2D-3D ハイブリッド計算における並列計算 の効率化について検討するとともに，より広領域の 3 次元領域を設定した解析を行う予定である.

\section{参考文献}

1) 凌国明, 松本純一, 樫山和男: 任意格子に基づくオーバー ラッピング手法を用いた 2 次元・ 3 次元ハイブリッド津 波解析手法, 土木学会論文集 A2(応用力学), Vol. 72, No. 2, pp. I_285-I_293, 2016.

2) Hirt, C.W., Nichols, B.D.: Volume of fluid method for the dynamics of free boundaries, Journal of Computational Physics, Vol. 39, pp. 201-225, 1981.

3) Beaucourt, J., Biben, T., Leyrat, A. and Verdier, C.: Modeling breakup and relaxation of Newtonian droplets using the advected phase field approach, Physical Review E, Vol.75, pp. 021405(1-8), 2007.

4) 松本純一，高田尚樹：非構造格子を用いた陰的有限要素 法による Multi-Phase-Field モデル流体解析, 計算工学講 演会論文集，Vol.20, CD-ROM, 2015.

5) 利根川大介, 樫山和男：安定化有限要素法による津波遡 上および流体力の解析手法の構築, 応用力学論文集, Vol. 12, pp. 127-134, 2009.

6) 桜庭雅明, 弘崎聡, 樫山和男：自由表面流れのための CIVA/VOF 法に基づく高精度界面捕捉法の構築，応用力 学論文集, 土木学会, Vol. 6, pp. 215-222, 2003.

7) Takase, S., Kashiyama, K., Tanaka, S. and Tezduyar, T.E.: Space-time SUPG formulation of the shallow-water equations, International Journal for Numerical Methods in Fluids, Vol. 64, pp. 1379-1394, 2010.

8) Kawahara, M., Umetsu, T.: Finite element method for moving boundary problems in river flow, International Journal for Numerical Methods in Fluids, Vol. 6, pp. 365-386, 1986.

9) 高橋佑典, 桜庭雅明, 樫山和男: 津波シミュレーションの ための CIVA-安定化有限要素法, 応用力学論文集, Vol. 70, pp. I_349-I_356, 2014.

10) Inamuro, T., Ogata, T., Tajima, S. and Konishi, N.: A lattice Boltzmann method for incompressible two-phase flows with large density differences, Journal of computational physics, Vol. 198, pp628-644, 2004.

11）高瀬慎介，加藤準治，森口周二，寺田賢二郎，京谷孝史， 野島和也，桜庭雅明，樫山和男：安定化有限要素法を用い た 2D-3D ハイブリッド手法による津波解析, 土木学会論 文集 A2(応用力学), Vol. 70, No. 2, pp. I_307-I_315, 2014.

12）樫山和男，西村直志，牛島省：並列計算法入門，計算力 学レクチャーシリーズ 3, 丸善株式会社，2003。

13) Gomez-Gesteira, M., Dalrymple, R.A.: Using a ThreeDimensional Smoothed Particle Hydrodynamics Method for Wave Impact on a Tall Structure, Journal of Waterway, Port, Coastal and Ocean Engineering, Vol. 130, pp63-69, 2004.

14) Synolakis, C.E.: The runup of solitary wave, Journal of Fluid Mechanics, Vol. 185, pp. 523-545, 1987.

15) Mansinha, L. and Smylie, D.E. : The displacement fields of inclined faults, Bulletin of the Seismological Society of America, Vol. 61, pp.1433-1440, 1971.

16) Satake, K., Fujii, Y. Harada, T. and Namegaya, Y.: , Time and Space Distribution of Coseismic Slip of the 2011 Tohoku Earthquake as Inferred from Tsunami Waveform Data, Bulletin of the Seismological Society of America, Vol. 103, pp. 1473-1492, 2013.

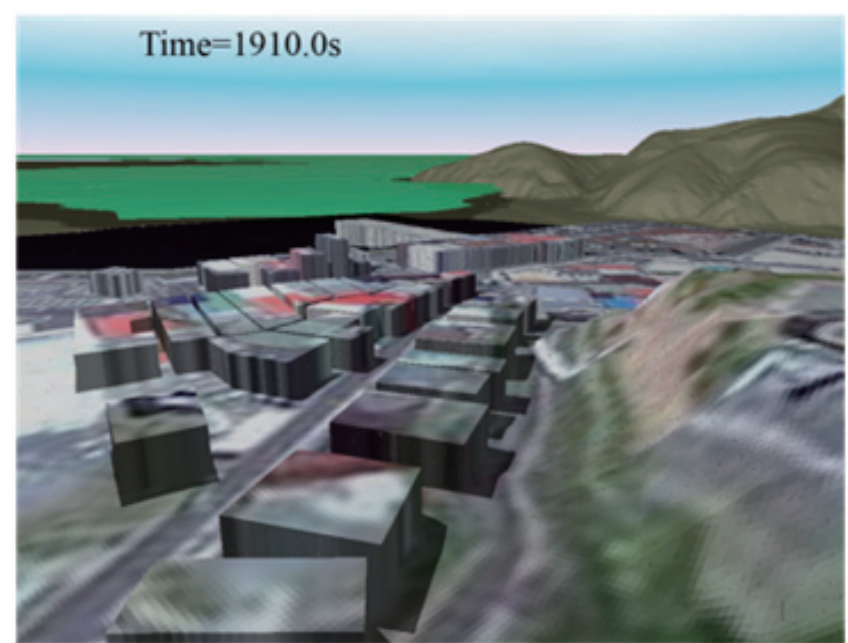

(A) $t=1,910 \mathrm{~s}$

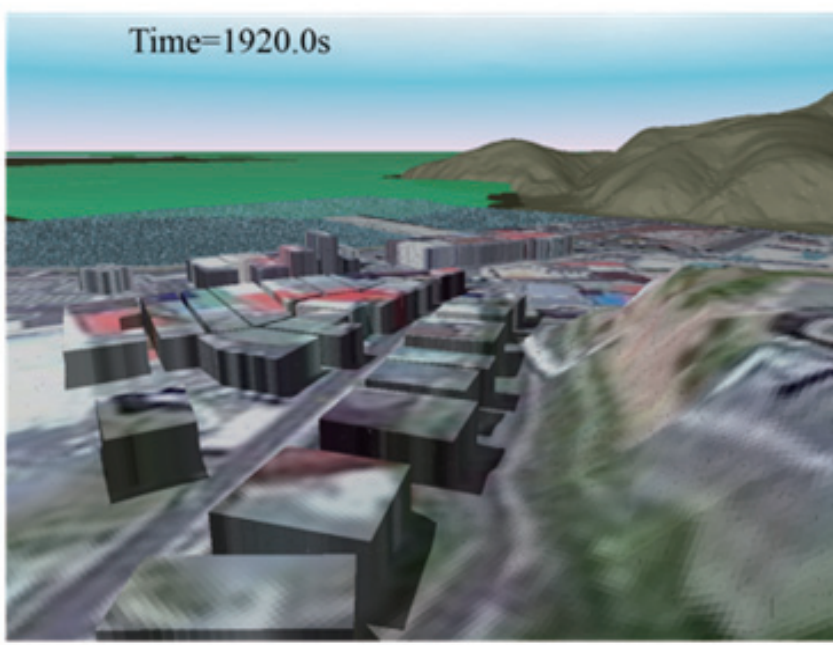

(B) $\mathrm{t}=1,920 \mathrm{~s}$

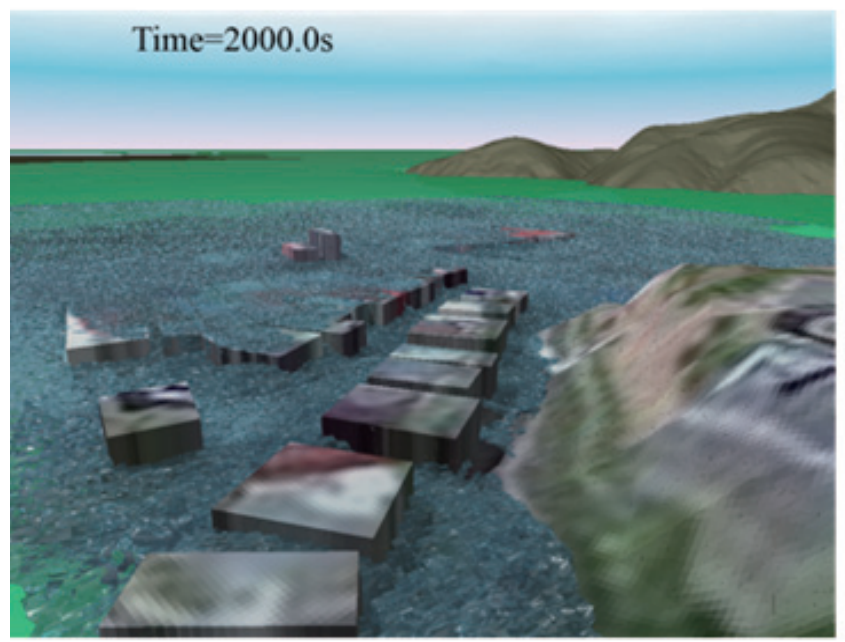

(C) $t=2,000 \mathrm{~s}$

図-19 高台（観測者）から見る解析結果 


\section{STUDIES ON ACCURACY AND LARGE-SCALE PROMOTION FOR THE 2D-3D HYBRID TSUNAMI ANALYSIS METHOD}

\section{Guoming LING, Junichi MATSUMOTO and Kazuo KASHIYAMA}

This paper presents investigation of accuracy and promotion of large-scale for the 2D-3D hybrid method based on the arbitrary domain. The Phase-Field Model (PFM) is applied to capture the free surface which is aimed to increase the accuracy for the 2D-3D hybrid method. The MPI method is used as the parallel computing method. Several numerical examples are examined to show the validity and the effectiveness of the presented method. Finally, the present model is applied to simulate the 2011 Tohoku tsunami. 